\title{
Orthodontic shear bond strength to porcelain surface in wet conditions
}

\author{
Magáli Beck Guimarães ${ }^{a}$, Bárbara Cocco $^{b}$, Rodrigo Salbego Bueno ${ }^{c}$, Micéli Beck Guimarães Blaya ${ }^{d}$, \\ Letícia Borges Jacques $^{e}$, Luciana Mayumi Hirakata ${ }^{\dagger}$
}

\begin{abstract}
Objective: To evaluate the shear bond strength of orthodontic accessories bonded to a porcelain surface after storage in water.

Methods: One-hundredand-twenty feldspathic porcelain discs were divided into 4 groups, according to the surface treatment: Group $1-37 \%$ phosphoric acid etching; Group $2-10 \%$ fluorhydric acid; Group $3-37 \%$ phosphoric acid and silane application; Group $4-10 \%$ fluorhydric acid and silane application. After the accessories were bonded, the sample was divided into two subgroups, according to the time interval of storage in distilled water: Control - 24 hours; and Test - 150 days. Shear bond strength was determined using a universal test machine, and failure type was verified by scanning electron microscopy.

Results: In the test groups there was reduction in shear bond strength, particularly when silane was used. Test Groups 2 and 4 presented shear bond strength values within those proposed as adequate for orthodontic bonding. Groups 1 and 3 presented adhesive failures between porcelain and resin, whereas in Groups 2 and 4 cohesive failures in porcelain were recorded.

Conclusion: Storage in water for 150 days decreased the bond strength at silanized interfaces. Fluorhydric acid etching generates adequate bond strength in wet conditions, however, increases the fracture rate in porcelain.
\end{abstract}

Key words: Shear strength; Dental porcelain; Dental bonding; Orthodontics

\section{Resistência ao cisalhamento de colagem ortodôntica em superfície de porcelana em condições úmidas resumo}

\section{RESUMO}

Objetivo: Avaliar resistência ao cisalhamento da colagem de acessórios ortodônticos a superfície de porcelana após armazenamento em água.

Metodologia: Cento e vinte discos de porcelana feldspática foram divididos em 4 grupos, de acordo com o tratamento de superfície: Grupo 1 - condicionamento com ácido fosfórico a 37\%; Grupo 2 - ácido fluorídrico 10\%; Grupo 3 - ácido fosfórico 37\% e silano; Grupo 4 -ácido fluorídrico 10\% e silano. Após a colagem dos acessórios, a amostra foi dividida em dois subgrupos, de acordo com o tempo de armazenamento em água destilada: Controle - 24 horas; e Teste - 150 dias. A resistência ao cisalhamento foi determinada utilizando-se uma máquina de ensaios universal, e o tipo de falha após a descolagem através de microscópio eletrônico de varredura.

Resultados: Nos grupos teste houve redução na resistência ao cisalhamento, particularmente quando o silano foi utilizado. Grupos Teste 2 e 4 apresentaram valores de resistência ao cisalhamento dentro daqueles propostos como adequados para colagem ortodôntica. Grupos 1 e 3 apresentaram falhas adesivas entre porcelana e resina, enquanto nos grupos 2 e 4 falhas coesivas em porcelana foram averiguadas.

Conclusão: Armazenamento em água por 150 dias diminui a força de adesão em interfaces silanizadas. Condicionamento com ácido fluorídrico gerou força de adesão adequada em condições úmidas; entretanto, aumentou a taxa de fratura em porcelana.

Palavras-chave: Resistência ao cisalhamento; Porcelana dentária; Colagem dentária; Ortodontia

\author{
a Assistant Professor, School of Dentistry, Franciscan \\ University Center, Santa Maria, RS, Brazil \\ ${ }^{b}$ Graduate Student, School of Dentistry, Franciscan \\ University Center, Santa Maria, RS, Brazil \\ ${ }^{c}$ Post-graduation Program in Dental Science, Santa \\ Maria Federal University, Santa Maria, RS, Brazil \\ ${ }^{d}$ Research fellow, Post-graduation in Orthodontics, \\ Franciscan University Center, Santa Maria, RS, Brazil \\ ${ }^{e}$ Associate Professor, Department of Restorative \\ Dentistry, Santa Maria Federal University, Santa \\ Maria, RS, Brazil \\ Associate Professor, Department of Pros- \\ thodontics, Pontifical Catholic University of Rio \\ Grande do Sul, Porto Alegre, RS, Brazil
}

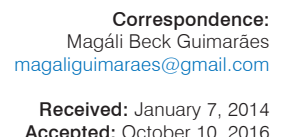

Accepted: October 10, 2016

Conflict of Interests: The authors state that there re no financial and personal conflicts of interest that could have inappropriately influenced their work.

Copyright: ( 2016 Guimarães et al.; licensee EDIPUCRS

This work is licensed under a Creative Commons Attribution 4.0 International License. 


\section{INTRODUCTION}

The increasing number of adult orthodontic patients has led to challenges for Dentistry professionals, as they are increasingly faced with the need for bonding orthodontic accessories to surfaces that differ from tooth enamel, such as in the case of restorations with porcelain surfaces $[1,2]$. In Orthodontics, orthodontic accessory bonding is temporary, therefore, the bond strength must be sufficient to resist the forces applied during treatment, and on the other hand, fragile enough to allow debonding at the end of treatment, without damaging the teeth and the restorations they may present [3]. Nowadays, ceramics are considered the material of choice for indirect restorations, particularly because of the advantages they offer, such as biocompatibility, high compressive strength and resistance to abrasion, chemical and color stability, radiopacity and excellent potential for simulating the appearance of natural teeth [4-6]. There are many protocols proposed in the literature for bonding orthodontic accessories to porcelain surfaces, and they vary right from the different acids applied for various periods of time through to airborne particle abrasion or application of bonding agents such as silane. Although there are innumerable protocols for bonding orthodontic accessories to porcelain, there is still no scientific consensus about which of the techniques would be the ideal standard protocol for the purpose of overcoming the two points of contrast mentioned above [7]. Thus, the aim of this study was to evaluate, in vitro, the shear bond strength of orthodontic accessories bonded to a porcelain surface under different bonding protocols, after storage in water, and the type of failure remaining on the porcelain surface after debonding of these accessories, in the different groups studied. The null hypothesis is that the humidity does not alter the shear bond strength between the orthodontic appliance and the porcelain surface in the experimental groups.

\section{METHODS}

The sample consisted of 120 feldspathic porcelain discs (Noritake EX-3, Noritake, Japan), randomly divided into four groups of 30 test specimens in each. Lingual buttons (ref. 3010205, Morelli Ortodontia, São Paulo, SP, Brazil) were bonded to the porcelain disk surfaces, using different porcelain surface treatment protocols, which characterized the research groups, as follows: - Group 1 (G1): Etching with 37\% phosphoric acid (Condac 37\%, FGM Produtos Odontológicos, Joinville, SC, Brazil) for 60 seconds; Group 2 (G2): Etching with 10\% fluorhydric acid (Condac Porcelana, FGM Produtos Odontológicos, Joinville, SC, Brazil) for 60 seconds; - Group 3 (G3): Etching with 37\% phosphoric acid (Condac 37\%, FGM Produtos Odontológicos, Joinville, SC, Brazil) for 60 seconds, followed by silane application (Prosil, FGM Produtos Odontológicos, Joinville, SC, Brazil); - Group 4 (G4): Etching with 10\% fluorhydric acid (Condac Porcelana, FGM Produtos Odontológicos,
Joinville, SC, Brazil) for 60 seconds, followed by silane application (Prosil, FGM Produtos Odontológicos, Joinville, SC, Brazil); After surface treatment, the adhesive system and resin composite (Transbond XT, 3M ESPE Dental Products, California, USA) were applied. Bonding was performed by a trained operator and the polymerization process was carried out for 40 seconds with a light polymerizing appliance (Ultralux, Dabi Atlante, São Paulo, SP, Brazil), with light intensity of approximately $480 \mathrm{~mW} / \mathrm{cm}^{2}$, gauged after every 10 samples using an analog radiometer (Gnatus, Ribeirão Preto, SP, Brazil). After the accessories were bonded, the sample with reference to each group was divided into two subgroups, according to the time interval of storage in distilled water at $37^{\circ} \mathrm{C}$ (Microbiological Oven, Nova Ética, São Paulo, SP, Brazil) (Table 1): Control - 24 hours; and Test -150 days. To apply the shear test, a universal test machine (EMIC, Model DL 2000, Equipamentos e Sistemas de Ensaios LTDA, Brazil) was used, connected to a computer to record the debonding forces. The test machine was calibrated with a $50 \mathrm{~N}$ load cell at a speed of $0.5 \mathrm{~mm} / \mathrm{min}$, according to the previously established methodology [8]. After debonding of the orthodontic accessories, the test specimens were analyzed by Scanning Electronic Microscopy (Phillips XL30, Eindhoven, Holland), at 35, 100, 500 and 1000X magnifications. Analysis of the entire sample was performed by a trained and blinded examiner. The images were classified as regards type of failure resulting from accessory debonding, as described below: - Cohesive in porcelain $(\mathrm{CP})$ - in the case of fractures or cracks in the porcelain surface; - Adhesive (A) - in the case when there was no failure in porcelain, or resin remainder on the porcelain surface, and all the resin was retained on the base of the orthodontic accessory; or when all the resin was adhered to the porcelain surface, without any remainder on the orthodontic accessory; - Cohesive in resin $(\mathrm{CR})$ - in the case when there was a resin remainder on the porcelain surface and at the base of the orthodontic accessory. To verify the normality of distribution of the data collected, the Kolmogorov-Smirnov non-parametric test was applied $(p>0.01)$. Thus, the mean shear bond strength values were compared among the groups by means of two-way ANOVA, followed byTukey's Multiple Comparison Test.

Table 1. Experimental design - Final division of the groups

\begin{tabular}{|c|c|c|c|c|c|}
\hline Group & $N$ & \multicolumn{2}{|l|}{ Porcelain Treatment } & $N$ & Group \\
\hline \multirow{2}{*}{1} & \multirow{2}{*}{30} & \multirow{2}{*}{ Phosphoric Acid } & Control & 15 & G1C \\
\hline & & & Test & 15 & G1T \\
\hline \multirow{2}{*}{2} & \multirow{2}{*}{30} & \multirow{2}{*}{ Fluorhydric Acid } & Control & 15 & G2C \\
\hline & & & Test & 15 & G2T \\
\hline \multirow{2}{*}{3} & \multirow{2}{*}{30} & \multirow{2}{*}{ Phosphoric Acid + Silane } & Control & 15 & G3C \\
\hline & & & Test & 15 & G3T \\
\hline \multirow{2}{*}{4} & \multirow{2}{*}{30} & \multirow{2}{*}{ Hydrofluoric Acid + Silane } & Control & 15 & G4C \\
\hline & & & Test & 15 & G4T \\
\hline
\end{tabular}




\section{RESULTS}

The behavior of the shear bond strength differed between the control and test groups in the different bonding protocols adopted (Table 2). A highest bond strength value was observed in Control Group 4, while in the test group the use of fluorhydric acid resulted in greater bond strength, irrespective of the use of silane $(p<0.001)$. In the specimens of the Control Group, the experiment that led to the lowest shear bond strength was the use of phosphoric acid, as there were significant differences among all the groups $(p<0.05)$, with exception of the result obtained between groups 3 and 4, whose values were shown to be equal $(\mathrm{p}>0,999)$. In the test specimens that underwent storage in

Table 2. Description of shear bond strength values according to groups

\begin{tabular}{cccccccc}
\hline \multirow{2}{*}{ Groups } & \multicolumn{3}{c}{ Control } & & \multicolumn{3}{c}{ Test } \\
\cline { 2 - 5 } & Mean & SD & N & & Mean & SD & N \\
G1 & $1.97^{\mathrm{aA}}$ & 1.01 & 15 & $0.96^{\mathrm{aA}}$ & 0.28 & 15 \\
G2 & $7.27^{\mathrm{bA}}$ & 0.64 & 15 & $9.67^{\mathrm{bB}}$ & 2.12 & 15 \\
G3 & $7.59^{\mathrm{bA}}$ & 2.22 & 15 & $4.18^{\mathrm{cB}}$ & 1.45 & 15 \\
G4 & $21.92^{\mathrm{CA}}$ & 2.84 & 15 & $10.24^{\mathrm{bB}}$ & 2.10 & 15 \\
\hline
\end{tabular}

* Different lower case letters indicate statistical difference between groups 1, 2, 3, and $4(\alpha=0.05)$.

** Different capital letters indicate statistical difference between control and test groups $(\alpha=0.05)$.

Table 3. Distribution of cohesive failure in porcelain.

\begin{tabular}{ccc}
\hline \multirow{2}{*}{ Groups } & \multicolumn{2}{c}{ Fractured porcelain (\%) } \\
\cline { 2 - 3 } G1 & Control & Test \\
G2 & 0 & 0 \\
G3 & 90 & 78 \\
G4 & 0 & 0 \\
\hline
\end{tabular}

water for 150 days, the shear bond strength was highest in Groups 2 and 4, which presented the same bond strength values $(\mathrm{p}=0,987)$. The lowest values were found in Group 1 . The shear bond strength in the Control Group was statistically higher than it was in the Test Group in the experiments using phosphoric acid associated with silane $(p<0.001$ and $\mathrm{p}<0.001$, respectively), denoting a probable degradation of this bonding agent. With fluorhydric acid, the bond strength was higher in the Test than in the Control Group $(\mathrm{p}=0.009)$. With the use of fluorhydric acid, the shear bond strength values in the control and test groups were equal $(\mathrm{p}=0.780)$. In Test Group 2, the rate of cohesive failure in porcelain was 78\%, while in Test Group 4, the rate of cohesive failure in porcelain was $89 \%$. Whereas in the Control Group, the rate of cohesive failure in porcelain was $90 \%$ and $60 \%$, respectively (Table 3 and Figure 1). Test and Control Groups 1 and 3 presented failures of an exclusively adhesive or cohesive nature in resin (Figure 1).

\section{DISCUSSION}

Techniques previously described for bonding orthodontic accessories to a porcelain surface vary in terms of surface preparation and type of bonding agent used. The use of both phosphoric and fluorhydric acid has been fully described, and so has the use of silane as a bonding agent between these surfaces $[9,10]$. Irrespective of the technique, for the materials used for orthodontic bonding or the surface to which these accessories will be bonded, it is suggested in contemporary literature that the ideal rupture force for the clinical success of orthodontic bonding is situated between 5.9 and $7.9 \mathrm{MPa}[11,12]$. Yadav et al [6] suggested the efficacy of the use of silane, which establishes a bond between the resin and porcelain surface. Studies have found that the use of silane as bonding agent may significantly increase the bond strength to porcelain before orthodontic accessory bonding. This result is due to its capacity to create the link
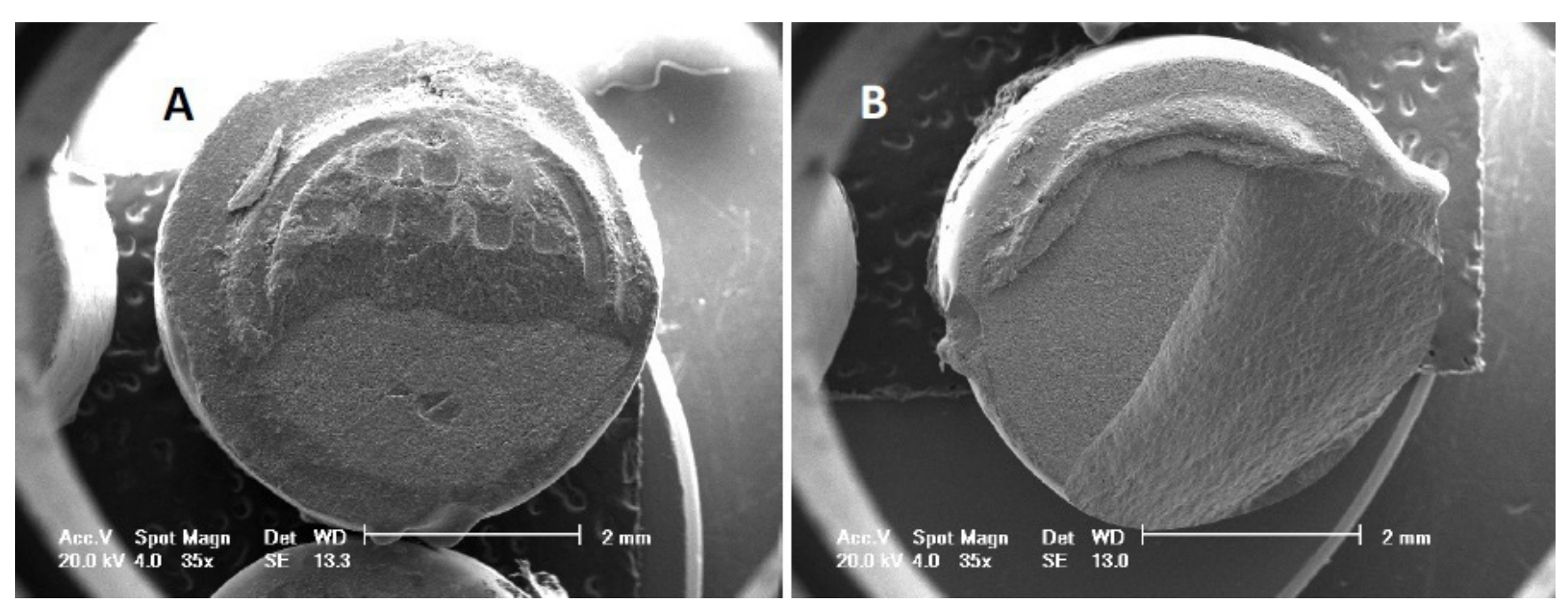

Figure 1. (A) Cohesive failure in resin found in porcelain surface in Group 3. (B) Cohesive failure in porcelain found in Group 4. 
between the silica in porcelain and the organic groups of the bonding resin, forming a bond between the two materials [9]. In the present study, simulation of the intraoral conditions of humidity and temperature was proposed, by means of storing the sample in distilled water for 150 days at a temperature of $37^{\circ} \mathrm{C}$, according to previously published methodo$\operatorname{logy}[13,14]$. In this condition, a significant reduction in bond strength occurred in the groups in which silane was applied. These results are corroborated by the study of Özcan et al. [13], in which it was related that storage in distilled water is potentially harmful to the adhesive bond between the ceramic surface and silane; and by the study of Brentel et al. [14], who suggested that silanized bond interfaces appear to be unstable in wet conditions. The lowest shear bond strength in this study was found in the group etched with phosphoric acid, irrespective of the time interval of storage in distilled water. The results were characterized by values that did not favor adequate bond strength, capable of resisting the forces applied during an orthodontic treatment $[11,12]$. However, when phosphoric acid was associated with silane, we found two different behaviors in the samples. The specimens that were submitted to storage in distilled water for 24 hours obtained a bond strength in accordance with that desired and proposed by the literature (7.59 MPa). However, when submitted to storage in distilled water for 150 days, this bond strength was reduced to a little over half of the original value (4.18 MPa). These results are in disagreement with those obtained by authors such as Larmour et al. [10] who, even after storing specimens in distilled water for a long period of time, obtained adequate bond strength in the group treated with phosphoric acid associated with silane $(7.9 \mathrm{Mpa})$. In the present study, a higher bond strength value was observed in the groups in which surface etching with fluorhydric acid was used, irrespective of association with silane in the Test Group. It should be remembered that although fluorhydric acid generally offers a higher bond strength, caution is recommended with its use, because its great toxicity to biologic tissues is widely known [10]. The Control Group 4, in which fluorhydric acid was associated with the use of silane, a mean shear bond strength of $21.92 \mathrm{MPa}$ was found, being a result similar to that found by Yadav et al. [6], in which the mean value was 20.8 MPa. Haydar et al. [12] mentions that there is no need for such an intense force in order to obtain adequate bonding of orthodontic accessories. In the present research, when the same group was stored in water for 150 days, the shear bond strength was reduced to $10.24 \mathrm{MPa}$, less than half the original value, but still within the bond strength considered clinically acceptable by the literature. In recent literature, it has been affirmed that the use of $37 \%$ phosphoric acid associated with silane as porcelain surface treatment may promote an adequate bond strength of orthodontic bonding, suggesting that its use would be more adequate than that of fluorhydric acid, since it offers lower risk to oral tissues (less toxicity), in addition to causing a lower number of irreversible failures in the restorative surface (cracks and fractures in porcelain) [15]. Nevertheless, in the present research it was observed that this bonding protocol, in wet conditions for 150 days, did not have favorable results, since the bond strength required for resisting the forces applied during an orthodontic treatment was not attained, being short of the desired value. In this study, it was observed that there were adhesive failures in the majority of the research samples, occurring mainly in the groups in which phosphoric acid was used. According to Mattos and Cappelli [16], failures of an adhesive nature, which occur at the adhesive/ porcelain interface, are considered more desirable because they do not leave residues or irreversible damage on the surface where bonding occurred. Failures of a cohesive nature in porcelain, characterized by cracks and fractures in porcelain, were found exclusively in the groups in which fluorhydric acid was used. In the control groups 2 and 4, the percentage of this type of failure was $90 \%$ and $65 \%$ respectively; while in the test groups there were $78 \%$ and $89 \%$ of these types of failures, respectively. Herion et al. [7] found that the use of fluorhydric acid followed by silane application significantly decreased the brightness and altered the color of the porcelain surface after orthodontic accessory debonding, denoting a great corrosive capacity of this acid. However, in the study of Mattos and Cappelli [16] no fracture in porcelain was found, even after this surface had been etched with fluorhydric acid. In view of the foregoing, and considering the limitations of this study, the authors suggest that the use of fluorhydric acid without the silane bonding agent appears to be the most adequate alternative for the proposed purposes, since it provides adequate bond strength for orthodontic bonding, with reduced changes of irreversible failures in porcelain, even in wet conditions. However, from the clinical point of view, it would seem to be prudent to alert patients, before orthodontic bonding, about the risk of damage to porcelain surfaces, and the possibility of requiring repair or replacement after the conclusion of orthodontic treatment. In addition, it is very important to remind professionals that it is imperative to take care in the handling of this acid to avoid accidents that may harm the patient biologically. It is recommended that further studies should be conducted in order to overcome the failures found, in addition to seeking other methods of etching and treatment of porcelain surfaces, capable of providing adequate bond strength without compromising the restorative treatment already performed. Lastly, as this concerns an in vitro study, extrapolation of its results associated with the clinical situation must be done with caution.

\section{CONCLUSION}

From the results obtained in the present research, it could be concluded that:

- Etching the porcelain surface with phosphoric acid with or without the silane bonding agent, after storage in water for 150 days, does not provide adequate shear bond strength, capable of resisting the forces applied during orthodontic treatment; 
- Storage in water for 150 days significantly decreased the bond strength at silanized interfaces, denying the null hypothesis;

- Surface conditioning with fluorhydric acid with or without silane generates adequate bond strength after storage in water, however, the use of this acid increases the fracture rate in porcelain.

\section{REFERENCES}

1. Turkkahraman $H$, Kuçukesmen HC. Porcelain surface-conditioning techniques and the shear bond strength of ceramic brackets. Eur J Orthod 2006; 28(5):440-3. https://doi.org/10.1093/ejo/cjl026

2. Habibi M, Nik TH, Hooshmand T. Comparison of debonding characteristics of metal and ceramic orthodontic brackets to enamel:An in vitro study. Am J Orthod Dentofacial Orthop 2007; 132(5):675-9. https://doi.org/10.1016/j. ajodo.2005.11.040

3. Atsu SS, Gelgor IE, Sahin V. Effects of silica coating and silane surface conditioning on the bond strength of metal and ceramic brackets to enamel. Angle Orthod 2006;76(5): 857-62. https://doi.org/10.1043/000 33219(2006)076[0857:EOSCAS]2.0.CO;2

4. Raptis NV, Michalakis KX, Hirayama H. Optical behavior of current ceramic systems. Int J Periodontics Restorative Dent 2006;26(1):31-41.

5. Henriques ACG, Costa DPTS, Barros KMA, Beatrice LCS, Filho PFM Dental Ceramics:current aspects, properties and indications. Odontologia Clín-Científ 2008;7(4):289-94.

6. Yadav S, Upadhyay M, Borges GA, Roberts WE. Influence of ceramic (feldspathic) surface treatments on the micro-shear bond strength of composite resin. Angle Orthod 2010;80(4):577-82. https://doi. org/10.2319/082409-481.1

7. Herion DT, Ferracane JL, Covel da Jr. Porcelain surface alterations and refinishing after use of two orthodontic bonding methods. Angle Orthod 2010;80(1):167-74. https://doi.org/10.2319/010909-19.1
8. Fox NA, Mccabe JF, Buckley JG. A critique of bond strength testing in orthodontics. Br J Orthod 1994;21(1):33-43. https://doi.org/10.1179/ bjo.21.1.33

9. Zachrisson YO, Zachrisson BU, Buyukyilmaz T. Surface preparation of orthodontic bonding to porcelain. Am J Orthod Dentofacial Orthop 1996;109(4):420-30. https://doi.org/10.1016/S0889-5406(96)70124-5

10. Larmour CJ, Bateman G, Stirrups DR. An investigation into the bonding of orthodontic attachments to porcelain. Eur J Orthod 2006;28(1): 74-7. https://doi.org/10.1093/ejo/cji072

11. Newman GV, Newman RA, Sun BI, HA JL, Ozsoylu SA. Adhesion promoters, their effect on the bond strength of metal brackets. Am J Orthod Dentofacial Orthop 1995;108(3):237-41. https://doi.org/10.1016/ S0889-5406(95)70015-3

12. Haydar B, Sarikaya S, Cehreli ZC.Comparison of shear bond strength of three bonding agents with metal and ceramic brackets. Angle Orthod 1999:69(5):457-62. https://doi.org/10.1043/00033219(1999)069<0457:C $\mathrm{OSBSO}>2.3 . \mathrm{CO} ; 2$

13. Özcan M, Pfeiffer P, Nergiz I. A brief history and current status of metal and ceramic surface conditioning concepts for resin bonding in dentistry. Quintessence Int 1998:29(11):713-24.

14. Brentel AS, Özcan M, Valandro LF, Alarça LG, Amaral R, Bottino MA. Microtensile bond strength of a resin cement to feldspathic ceramic after different etching and silanization regimens in dry and aged conditions. Dent Mater 2007:23(11):1323-31. https://doi.org/10.1016/i.dental.2006.11.011

15. Guimarães MB, Lenz HF, Bueno RS, Blaya MBG, Hirakata LM Orthodontic bonding to porcelain surfaces:In vitro shear bond strength Rev Odonto Ciênc 2012;27(1):47-51. https://doi.org/10.1590/S198065232012000100009

16. Mattos AM, Capelli Junior J. Porcelain surface evaluation after debonding of orthodontic brackets. Rev Dent Press Ortodon Ortop Facia 2006:11(5):151-8. https://doi.org/10.1590/S1415-54192006000500016 